\title{
Why Hotels? Economy Weakens but Hotels Remain Relatively Strong- What Gives? And What Might Give?
}

Cornell Haspitality Quarterly $53(4)$ 270-273

(6) The Author(s) 2012

Reprints and permission:

sagepub.com/|aurnalsPermissions. nav DOI: | 0.1 | 77// 9389655 | 2460500 http://cqx.sagepub.com

(9)SAGE

\author{
Jack Corgel' and Mark Woodworth ${ }^{2}$
}

\begin{abstract}
Despite tepid economic indicators, the demand for hotel rooms in the United States has surged since the depths of the great recession in 2009. Bucking all apparent economic trends, lodging has been a leading industry during this sluggish economic recovery. This is different from past recovery periods when hotels typically lagged other industries. In this article, the authors identify and explain the economic forces behind the growth in lodging demand during the recovery. Then they examine future changes in lodging demand based on two different economic forecast scenarios.
\end{abstract}

\section{Keywords}

hotel economics, hotel demand, lodging cycle, hotel forecast
Recent news reports on the condition of the U.S. economy provide support for what many economists predicted would happen during the second half of 2012 - the economy will become weaker than the less-than-robust first half of the year. In his latest testimony to Congress, Federal Reserve Chairman Ben Bernanke wore a gloomy face and delivered an equally dour forward assessment of domestic economic conditions. Based on preliminary data from Smith Travel Research (STR) for the month of July, it appears that our prediction from back in January that the third quarter of 2012 will be the weakest quarter of the year for the lodging industry, in terms of year-over-year change, has begun to play out.

Looking back to the depths of the great recession and the lodging industry trough of three short (or perhaps long) years ago, the U.S. hotel industry recovery thus far has outdistanced that of most other sectors of the domestic economy. During the past two and a half years, gross domestic product (GDP) growth averaged 2.3 percent, whereas hotel average daily rates (ADRs) increased a cumulative 7.7 percent. This raises questions. Will an even slower economy soon squelch business and leisure traveler's appetite for trips? When travelers think about where they will stay and what price to pay for hotel rooms in the months and year ahead, how will their behaviors change with news of a more pronounced economic slowdown? How much will financial performance suffer if people spend more nights in their own beds? We have given careful thought to these questions. This may seem surprising, but we believe that the answer to all these questions is not much! Here's why.
From the beginning of the recovery, PKF Hospitality Research, LLC, has maintained that sound economic logic underlies the robust hotel turnaround during a slow general economic recovery. To a certain extent, recovery period growth rates are amplified by rebound arithmetic as yearover-year comparisons are made with cyclical trough history. Hotel occupancies took a serious peak-to-trough dive of 14.1 percent, whereas the declines in other sectors of the economy were not as severe. Hence, as hotels have begun to fill up again, growth rates may appear exaggerated. Nevertheless, the economic and behavioral explanations for hotel financial performance during the past two years are compelling. Business and leisure travelers make commitments to trips because of immediate needs or desires, they have the economic wherewithal to do so, and they are not fearful of personal harm or economic threats. The specifics are as follows:

1. To paraphrase the Ragin' Cajun, James Carville, It's Income, Stupid: Economists at PKF Hospitality Research have econometrically estimated literally thousands of demand models and learned from the experience that direct measures of business and leisure travelers' spending capacity,

'Cornell University

${ }^{2}$ PKF Hospitality Research

\section{Corresponding Author:}

Jack Corgel, Cornell University, 450 Statler Hall, Ithaca, NY 14853, USA Email: jc8I@cornell.edu 
such as real personal income and corporate profits, explain hotel demand as well and more consistently than other economic variables. This is particularly true among the higher priced category of hotels, which have been leading the industry along the path to recovery since mid-2010. Real personal income has been growing at a 2.5-percent rate, and according to Moody's Analytics is expected to grow by 3.0 percent over the next eighteen months. Similarly, corporate profits have increased 6.6 percent over the past year and a half and corporate balance sheets are strong.

2. Employment specifics matter: The strong hotel industry recovery from the 2008 financial crisis and 2007 to 2009 recession was least damaging to the domestic leisure travelers who occupy hotel rooms in the upper portion of hotel chain scales (i.e., luxury, upper upscale, upper midprice, and some midprice). The unemployment rate for college-educated people has remained at slightly over 4.0 percent and thus the weak economy has supplied jobs to new workers in this category and has not created widespread fear that these educated workers would lose their jobs. A careful look at the U.S. Department of Labor, Bureau of Labor Statistics data on unemployment by education and by job type reveals that our nation's employment problem is concentrated in the unskilled labor force.

3. Foreign aid: Hotel room sales have benefited from international travel to the United Statesa sort of nongovernmental "foreign aid" to the industry! These sales are only meaningful in gateway cities, but according to U.S. Department of Transportation and International Trade Association data, expenditures by foreign travelers to the United States and enplanement from origins outside the United States exceeded historic peaks during 2011. Problems in Southern Europe put only a small kink in the upward trend line.

4. Supply < demand: It takes roughly 1.0 percent growth in the supply of hotel rooms to replace units permanently taken out of service. During the past two years, U.S. hotel room supply has been growing at a rate of approximately 0.5 percent. During the same period, the number of rooms sold has increased at a 5.5-percent rate. With a modest number of hotels currently under construction, and absent a catastrophic event that tanks the economy, it will be years (not quarters) before supply growth meets demand growth. The June 2012 Hotel Horizons ${ }^{(2)}$ national demand forecast for 2013 is 2.0 percent.
We do not have our heads in the sand about the weakened state of the U.S. economy and the potential damage that further erosion could do to traveler confidence. If real personal income growth rates shift downward, if unemployment rates rise for skilled workers, if the trend reverses for international travel to the United States, or if the pace of supply growth overtakes demand, our forward perspective on the industry will dramatically change.

But for now, the months ahead present a clear positive picture. Data from the July 2012 TravelClick North American Hospitality Review found that the committed hotel occupancy for the third quarter of 2012 through the second quarter of 2013 (or the next twelve months) is up 6.1 percent in comparison with same time last year, with twenty of the top twentyfive North American markets showing increases in committed occupancy for this time period. ADR is also growing, with an increase of 5.5 percent over the same time last year.

\section{The Expected Case Scenario}

We rely on the economic forecasts prepared by Mark Zandi and his team at Moody's Analytics. Their most probable scenario is what drives the "expected case" forecasts that we develop quarterly for fifty of the largest U.S. hotel markets, each of the six STR chain scales (e.g., luxury, upper upscale, upscale) and location types (i.e., urban, suburban, airport, resort, highway, small town). In aggregate, these groups comprise our Hotel Horizons ${ }^{\circledR}$ forecast universe.

\section{Highlights of the Expected Case Economic Outlook}

Based on updated forecasts from Moody's Analytics and actual first-half 2012 data from STR, we are revising our revenue per available room (RevPAR) forecasts for 2012 upward. We now expect the national occupancy level to increase 2.5 percent this year (up from $1.6 \%$ in our previous forecast) and ADRs to grow by 4.2 percent (instead of $4.1 \%$ ). This yields a RevPAR growth of 6.8 percent, a full point above our prior estimate of 5.8 percent. Because market performance is getting better at an accelerated pace, we have lowered our RevPAR estimates for 2013 to 6.3 percent, slightly below our previous estimate of 6.6 percent. Characteristics of the economic scenario from Moody's Analytics that support this view are as follows:

- The U.S. economy is growing but uncomfortably slowly. Real GDP is expanding no faster than 2.0 percent at an annual rate, and recent payroll job gains have averaged 75,000 per month. At this pace, unemployment will remain stuck above 8.0 percent for some time. 
Exhibit 1:

Economic Assumptions

\begin{tabular}{|c|c|c|c|c|c|c|}
\hline \multirow[b]{2}{*}{ Year } & \multicolumn{2}{|c|}{ Real Personal Income } & \multicolumn{2}{|c|}{ Employment } & \multicolumn{2}{|c|}{ GDP } \\
\hline & $\begin{array}{l}\text { Expected } \\
\text { Case (\%) }\end{array}$ & $\begin{array}{c}\text { Alternative } \\
\text { Case (\%) }\end{array}$ & $\begin{array}{l}\text { Expected } \\
\text { Case (\%) }\end{array}$ & $\begin{array}{c}\text { Alternative } \\
\text { Case (\%) }\end{array}$ & $\begin{array}{l}\text { Expected } \\
\text { Case (\%) }\end{array}$ & $\begin{array}{l}\text { Alternative } \\
\text { Case (\%) }\end{array}$ \\
\hline \multicolumn{7}{|c|}{ First/second half 2012 , annual change } \\
\hline First half 2012 & 0.7 & 0.7 & 1.3 & 1.3 & 1.9 & 1.9 \\
\hline Second half 2012 & 2.3 & 1.3 & 1.3 & 0.4 & 2.2 & 0.6 \\
\hline \multicolumn{7}{|c|}{2012 and 2013 , annual change } \\
\hline 2012 & 1.6 & 1.0 & $\mathrm{I} .4$ & 0.9 & 2.1 & 1.3 \\
\hline 2013 & 2.8 & 0.1 & 1.4 & -2.0 & 2.6 & -2.5 \\
\hline
\end{tabular}

Source: PKF Hospitality Research, LLC and Moody's Analytics.

Note: GDP = gross domestic product.

- The U.S. outlook depends critically on what governments do in the United States and elsewhere in coming months.

- Europe's problems are causing U.S. employers to hold back from investment and hiring.

- Assuming policymakers get it roughly right; the U.S. economy is expected to gain traction going into 2014 and to return to full employment- a sub6.0-percent jobless rate- by late 2015 .

- Falling over the fiscal cliff means a new U.S. recession. The tax increases and spending cuts slated to hit next year equal more than 4.5 percent of GDP. The mix of tax cuts and spending increases will vary depending on who wins the presidency, but the end result will not be much different considering there will be a divided Congress.

\section{What Happens if the \\ Expected Case Is Too Optimistic?}

The depth and breadth of economic and political turmoil, both domestically and abroad, has served to heighten uncertainty in the minds of both consumers and business leaders. More to the point, there are many reasons for industry participants to place a low probability on the expected case economic outlook. As such, we turned to Moody's Analytics for guidance as to what a less-robust turn of events might look like for the months and year ahead. We developed a hybrid of two alternative economic scenarios from Moody's Analytics that while less probable than the expected case seems plausible. This alternative case economic outlook is characterized as follows:

- Europe has a deeper second recession as Greece has a disorderly departure from the euro zone, and investors increasingly worry that other highdebt countries such as Portugal and Spain will be next.

- Uncertainty deepens about whether U.S. policymakers will successfully address the turning point in the federal deficit in early 2013 and disagreements in Congress over priorities prevent initiatives that might soften the second downturn.

- The U.S. stock market falls sharply in 2013 and corporate bond spreads rise above the baseline trend, weakening business investment and hiring.

- The decline in GDP causes the labor market to contract throughout most of 2013, and another wave of consumer retrenchment ensues.

- The contraction in the labor market causes the unemployment rate to hit a peak of 12.6 percent in the third quarter of 2013.

If we look back in the second half of 2013 and see that the economic scenario described above turns out to be highly accurate, what will the domestic lodging industry look like? What happens to our forecast of a 5.8 percent RevPAR gain in 2012 and another 6.6 percent lift in 2013 ?

Exhibit 1 contains a comparison of three key economic variables that drive our lodging forecasts for both the expected case and the alternative case. If real personal income growth, employment, and the change in GDP "hit a cliff" in line with the alternative case scenario shown in Exhibit 1, the damage to the lodging industry is significant, as the 2013 ratios would swing to negative (see Exhibit 2). Travel of all types would diminish substantially, and occupancies and room rates experience a dramatic contraction - not as severe as what was 
Exhibit 2:

Alternative Lodging Forecasts

\begin{tabular}{|c|c|c|c|c|c|c|}
\hline \multirow[b]{2}{*}{ Year } & \multicolumn{2}{|c|}{ Occupancy } & \multicolumn{2}{|c|}{ ADR } & \multicolumn{2}{|c|}{ RevPAR } \\
\hline & $\begin{array}{l}\text { Expected } \\
\text { Case (\%) }\end{array}$ & $\begin{array}{c}\text { Alternative } \\
\text { Case (\%) }\end{array}$ & $\begin{array}{l}\text { Expected } \\
\text { Case (\%) }\end{array}$ & $\begin{array}{c}\text { Alternative } \\
\text { Case (\%) }\end{array}$ & $\begin{array}{l}\text { Expected } \\
\text { Case (\%) }\end{array}$ & $\begin{array}{c}\text { Alternative } \\
\text { Case (\%) }\end{array}$ \\
\hline \multicolumn{7}{|c|}{ First/second half 2012 , annual change } \\
\hline First half 2012 & 3.4 & 3.4 & 4.4 & 4.4 & 8.0 & 8.0 \\
\hline Second half 2012 & 1.5 & -0.5 & 4.0 & I.I & 5.6 & 0.6 \\
\hline \multicolumn{7}{|c|}{2012 and 2013 , annual change } \\
\hline 2012 & 2.5 & 1.3 & 4.2 & 2.7 & 6.8 & 4.0 \\
\hline 2013 & 1.2 & -4.5 & 5.0 & -2.8 & 6.3 & -7.2 \\
\hline
\end{tabular}

Source: PKF Hospitality Research, LLC, STR (historical data).

Note: $A D R=$ average daily rate; RevPAR = revenue per available room.

seen in 2009, but still very damaging. Under this scenario, the lodging industry turns from being one of the most significant producers of new jobs to once again letting employees go in the face of steep revenue declines. We can hope this alternative scenario does not come to pass, but time will tell.

\section{Declaration of Conflicting Interests}

The author(s) declared no potential conflicts of interest with respect to the research, authorship, and/or publication of this article.

\section{Funding}

The author(s) received no financial support for the research, authorship, and/or publication of this article.

\section{Bios}

Jack Corgel is the Robert C. Baker professor of real estate at the Cornell University School of Hotel Administration and Senior Advisor to PKF Hospitality Research, LLC.

Mark Woodworth is president of PKF Hospitality Research, LLC. 